\section{Shoreham nuclear power plant shuts, Seabrook stumbles}

\section{Boston}

Shoreham and Seabrook, the neverlicensed nuclear power plants in New York and New Hampshire, have finally sunk under the weight of a decade's political and financial opposition.

Shoreham's death became official two weeks ago, when the Long Island utility LILCO formally agreed to sell the unopened $\$ 5,000$-million plant to New York state for $\$ 1$. As part of the agreement, the state will oversee the closure and, ultimately, the dismantling of the plant.

LILCO will, as a result, take a loss on paper of $\$ 2,500$ million, but will be allowed to pass some of the rest of the cost onto its consumers. LILCO's electricity rates, already the second highest in the United States, will also be raised by 5 per cent a year. Meanwhile, investors in the plant have already suffered much of the remaining financial loss — the price of LILCO's stock has plummeted during the plant's demise.

State officials have not yet decided what to do with the plant they have acquired for $\$ 1$. The state says plainly that it intends to dismantle the reactor, but how and when is far from clear. At present, there is no place in the United States at which to dispose of the fuel rods (radioactive because of low-level operation) and reactor parts; there will probably not be a licensed disposal site until next century.

The proposed high-level nuclear waste

repository, originally planned to open in 1996, has yet to be started. Indeed, it is not yet clear whether the proposed site in Yucca Mountain, Nevada, will meet the Energy Department's geological and environmental criteria.

Another possibility for New York state is to mothball the plant in such a way that it could be reopened at a future date if warranted. So far, no nuclear plant in the United States has been dealt with in this way, and observers say that the obstacles to such a course are high. For one thing, Shoreham would need to retain a licence, which itself costs close to $\$ 1$ million a year, while the cost of the skeleton staff that would be necessary to maintain the reactor's operating potential would be higher still.

Although its ultimate fate has yet to be decided, the Shoreham plant is now certain to be shut down. But New Hampshire's Seabrook plant is still on its deathbed. The latest development is that one of the plant's largest remaining investors announced its intention to pull out, sundering the fragile investment coalition on which the plant depends.

The governor of Massachusetts, Michael Dukakis, who is foremost in the race for the Democratic nomination for the presidential election in November, has consistently opposed Seabrook and, if elected president, would most certainly shut the plant down.

Seth Shulman

\title{
Rain-making experiment in India
}

\section{New Delhi}

THE Indian Department of Science and Technology (DST) has defended its financial support of an extraordinary rainmaking experiment that was supposed to invoke the rain god through a 3,000-yearold religious ritual described in Vedas, the holy scriptures of the Hindus.

The ritual, called yagna, involves chanting of vedic hymns in praise of the god Varuna before a sacred fire kept burning with twigs of herbs and a large quantity of clarified butter (ghee).

The officially sponsored yagna took place last week at Mathura, about $100 \mathrm{~km}$ from New Delhi, and was performed by an 86-year-old vedic scholar who claims that nine of the twelve yagnas he has performed in the past eight years brought rain.

Sharma chanted verses from Sama Veda before a fire kept burning six hours a day for a week with $100 \mathrm{~kg}$ of sandalwood and 15 selected herbs, and an equal quantity of ghee. As loudspeakers blared the vedic chants, scientists of the Indian Meteorological Department (IMD) using scientific equipment monitored changes in the atmosphere that Sharma claimed his exercise would bring about. The scientists also collected samples of aerosols from the fire that supposedly had the power to attract clouds and induce rain.

A spokesman for DST said the yagna was part of IMD's continuing programme of "cloud-seeding using ground-based generators". He said Sharma's proposal was funded only after approval by a committee of physicists and meteorologists as it presented an opportunity scientifically to evaluate the validity of the ancient Hindu rite for creating artificial rain.

The yagna fire in Mathura failed to bring even a drop of rain but has landed DST in the fire. The experiment is widely interpreted as official sanction to superstition at a time when Prime Minister Rajiv Gandhi is exhorting scientists to take India into the twenty-first century. The DST, which tried to keep the yagna a secret from the press, says it was only following "the scientific tradition of being objective and openminded".

\section{Agreement on minerals}

\section{Washington}

AN agreement for regulating the development of Antarctica's mineral resources was reached last week between 33 countries that have interests in the continent. No immediate plans have been laid to exploit Antarctica's mineral and petroleum reserves.

The agreement replaces an informal moratorium on mineral development that has been observed by all nations for the past eight years. It outlines a framework for controlling every aspect of development, from prospecting and exploration activities to mineral extraction and processing, and puts priority on protecting the Antarctic for research purposes.

The extent of Antarctica's natural mineral resources has not yet been determined, but because of its size, it is suspected to contain commercially valuable minerals and petroleum. The high cost of mining in the Antarctic environment will make development unlikely until sources elsewhere are depleted.

The agreement is the latest under the Antarctic treaty system, begun in 1959 by the 12 countries that first sponsored research expeditions to Antarctica. The initial treaty was set up to preserve Antarctica for pure research: it bans military and nuclear activities, and guarantees freedom to conduct scientific research to all countries that respect these bans, as long as they share their data. Since 1959, eight more countries have initiated research programmes and become parties to the original treaty. Eighteen additional countries have indicated their approval, but do not have a vote in decisions under the treaty system because they have not conducted Antarctic research. In 1980 a second treaty governing the harvesting of fish and other wildlife was signed.

Negotiations concerning the new agreement on mineral resources stretched over six years, and were complicated by territorial claims made by Argentina, Chile, Australia, Britain, France, Norway and New Zealand - seven of the original 12 signatory nations to the Antarctic treaty system. These "claimant" states will be balanced against non-claimants, including the United States and the Soviet Union, on the review commission established by the agreement to regulate development. The new agreement will attain treaty status once it is signed and ratified by 16 of the 20 voting parties in the Antarctic treaty system, expected by the end of the year.

Many environmental groups, including the Antarctic and Southern Ocean Coalition, a consortium of 176 organizations, oppose the agreement.

Carol Ezzell 